\title{
Béla Oláh
}

\section{Comparison of early maturity maize hybrids in function of the average yield in year 2012}

Oláh Béla: Korai érésű kukorica hibridek 2012. évi összehasonlítása a termésátlag függvényében

\section{Summary}

The main goal of this scientific paper is the comparison of outstanding hybrids of the three largest, world-leading maize hybrid seed developers and suppliers (Monsanto, Pioneer and Syngenta) in function of the average yield and grain moisture. The author's investigations were executed on a 600 hectare farm in the south of the Békés County in the extreme drought year of 2012. The examined hybrids were the DKC 4590 (FAO 360), the P9494 (FAO 390) and the NK Lucius (FAO 330). All three hybrids fall under the early maturity group (FAO 300-399).

Keywords: maize hybrid, seed producer, drought, average yield, grain moisture

\section{ÖSSZEFOGLALÓ}

Jelen tudományos munka a világ három legnagyobb, vezetö kukorica hibrid vetömagnemesítő és forgalmazó vállalatának (Monsanto, Pioneer, illetve Syngenta) egy-egy kiemelkedö hibridjét hasonlítja össze. Mivel a hibridek megválasztásakor fontos szempont a termöképesség és a vízleadó képesség, így a dolgozat szintén ezek függvényében vizsgálja $a z$ eredményeket. $\quad A$ szerző kísérletei a 2012-es, rendkívül aszályos évben egy több száz hektáron gazdálkodó délbékési családi vállalkozásnál készültek. A vizsgált hibridek a DKC 4590 (FAO 360), a P9494 (FAO 390), valamint az NK Lucius (FAO 330) voltak. Mindhárom hibrid a korai éréscsoportba (FAO 300-399) tartozik és technológiai szempontból is ugyanazt kapta.

Kulcsszavak: kukorica hibrid, vetömag-elöállitó, aszály, termésátlag, szemnedvesség

\section{INTRODUCTION}

Two years ago, the country's corn production fell low due to the extreme drought similarly to the situation in 2007 (Figure 1).

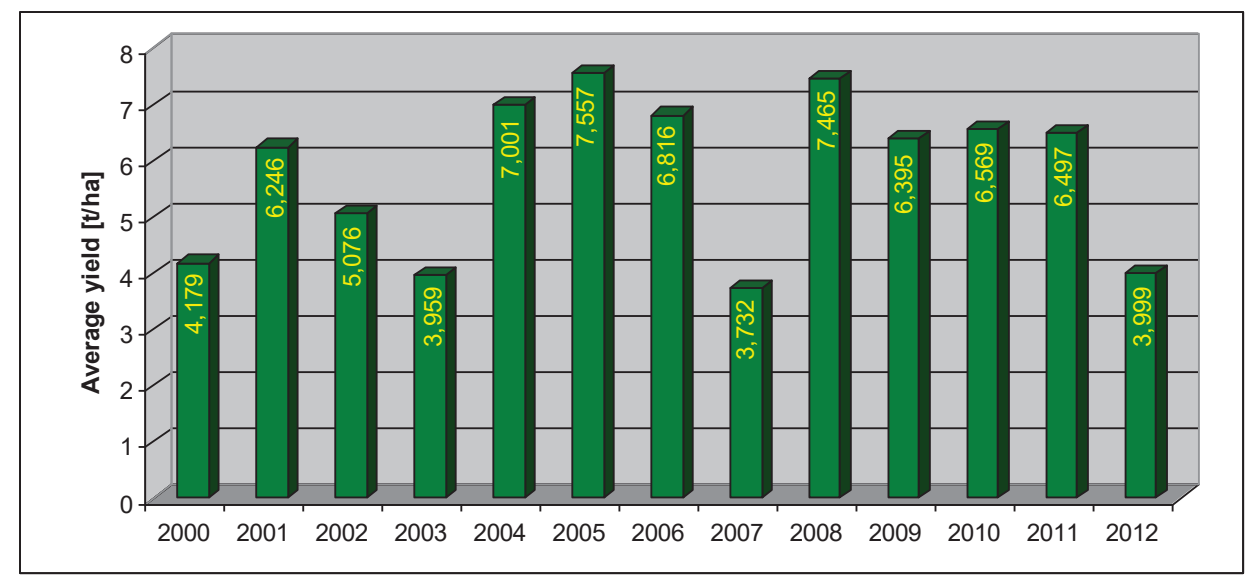

Fig. 1. The national average yield of corn per year [8]

In 2012, the yield level was dramatically low ( $3.98 \mathrm{t} / \mathrm{ha}$ ) because of the combined impact of the extremely low precipitation $(-96 \mathrm{~mm})$, and higher $\left(+1.4^{\circ} \mathrm{C}\right)$ average temperature compared to the long term mean. But the seed producers do their best to produce hybrids suitable to Hungary's climate and soil conditions. 
In our country Pioneer, Monsanto and Syngenta play the main role in corn seed distribution market. In Hungary about one third of all sown seeds were Pioneer hybrids for many years, the second ranking was Monsanto slightly behind with the results of over $30 \%$, and Syngenta came third with a stable approx. 12 per cent [9]. All these three multinational companies have their own seed plants in our country in order to meet the growing Hungarian and EastEuropean needs. Figure 2 shows the corn seed market share in Europe [11].

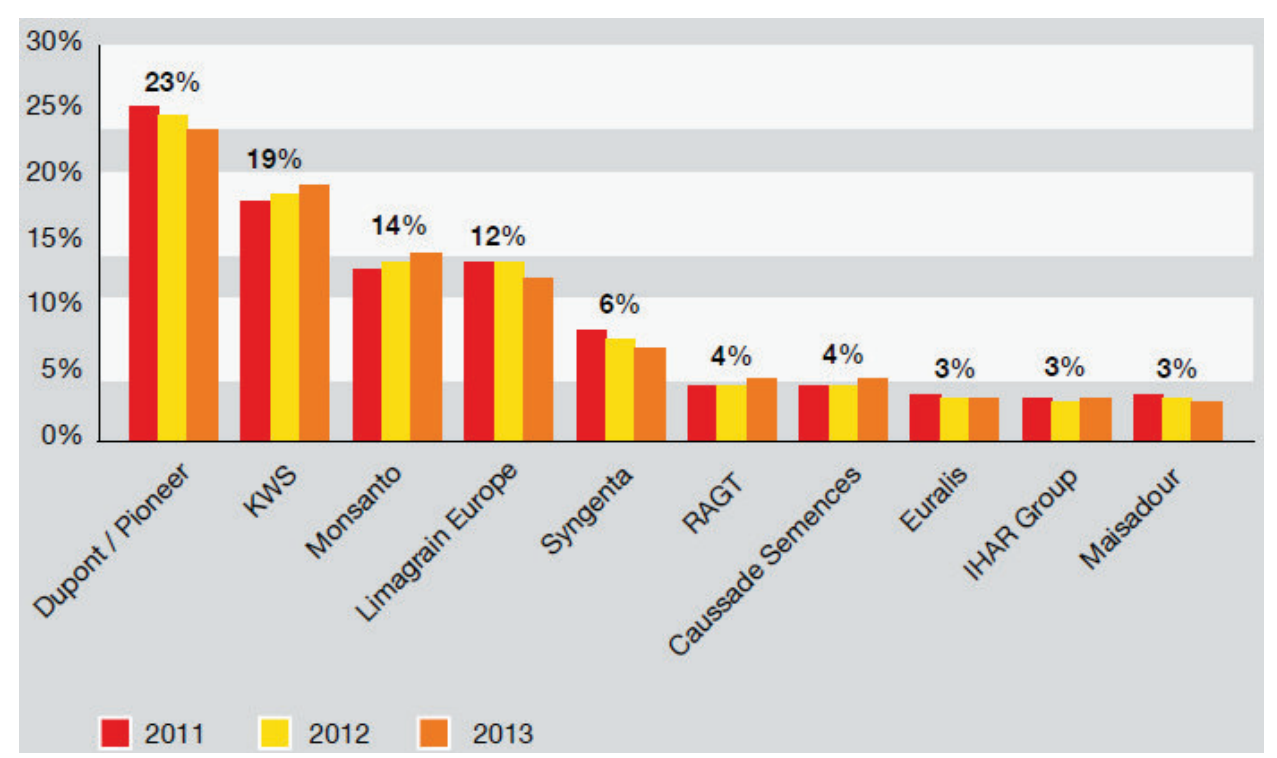

\section{EXAMINED HYBRIDS}

\section{DKC 4590}

DKC 4590 belongs to the FAO 360 maturity group. It represents a new genetic line, which provides high performance. It is able to produce a stable, top yield. It is a hybrid for the extreme climate of East-Europe selected on the basis of the breeding experiments by Hungary and neighbouring countries. Medium-tall plants with strong stalks that are not liable to lodge. The imposing (long, wellfertilized, cylindrical) ears hold out the promise of outstanding yield at first sight. Grain type: dent. It tolerates the stress well during the whole growing season. It has outstanding stability in terms of weather and production site. It produces excellent yields in both

Fig. 2. Corn seed market share in the EU Source: Kleffmann Corn Panels

In our country, with regard to corn hybrids, the FAO 300 maturity group is the dominant (because these suit best the Hungarian climatic conditions) therefore they became the author's choice of hybrids for early maturity (FAO 300399). The varieties tested were DKC 4590 (Monsanto), NK Lucius (Syngenta) and P9494 (Pioneer).

Nowadays in Hungary only about $2 \%$ of the total agricultural area - and within the corngrowing sites too - is irrigated (about 100,000 hectares). Among the 28 EU Member States, Hungary ranks the 26th regarding the size of irrigated areas. Therefore, this research was also conducted in dry conditions. drought and wet years. Its all important qualities are between the best in its maturity group. It was the most stable high yield potential hybrid in the previous three years by the independent experiments and the farmers' experiences as well.

DKC 4590 has excellent productivity and yield stability, which was confirmed in the years with different amounts of rainfalls. It was able to produce a balanced yield in the extremely wet year of 2010 and in the drought year of 2011, too. In 2011, it was the 6th most favourite hybrid in Hungary, its growing area was about 40,000 hectares (more than double large than in 2010).

This hybrid performed also excellently in the comparative small plot examinations in year 
2011, proved its excellent drought tolerance (under such stress conditions - after ranking third in 2010 - its average yield exceeded those of the competitors by $1.5 \mathrm{t} / \mathrm{ha}$, with equal grain moisture content):

- maize hybrids (on small plot, postregistration, comparative variety) trials by the Grain Producer's Association-Hungary and the Hungarian Seed Association (GOSZVSZT) - it ranked first in the early maturity group;

- TOP 20 trials by Hungarian Maize Club (MKK) - ranking third in FAO 300 maturity group [5].

\section{NK LUCIUS}

It is an outstanding productivity hybrid. It belongs to the lower third of the FAO 300 maturity group. This is the most important variety of the Syngenta's hybrids. Its growing area was more than 40,000 hectares in 2011. It has a thick, strong stalk and smaller height than the average. Its root is strong, not liable to early root-lodge. During maturing the husks become loose. Kernels are deeply set and easily shelled, the cobs are slim. The number of grain rows amount to $16-18$, sometimes 20 , but sometimes there are 22 rows on the cob under better circumstances than the average. This hybrid has shown excellent yield stability in different years. Its high productivity and good adaptability was proved in both small plot trials and large scale experiments. It is recommended for every production site and with different soil types. NK Lucius has very fast drying down capacity.

In 2006, the hybrid excelled with its high yield and low grain moisture at harvest under good growing conditions. Its good drought tolerance was demonstrated in the droughty year of 2007. On small plot trials conducted by Central Agricultural Office $(\mathrm{MgSzH})$, it ranked first in the FAO 300 group in 2008. Lucius ranked first regarding both the absolute ranking and the yield-grain moisture ratio in its group. In the examination carried out by the Hungarian Maize Club (MKK) it ranked 5th in the total ranking and second in the early maturity group.
It showed outstanding efficiency in the product development trials too [4].

\section{P9494}

Its FAO number is 390 , ripening at the end of the 300 maturity group, record yielding, typically dent maize hybrid. It has favourable agronomical characteristics, its root and stalk is strong. Ears grow low on the stalks. It has excellent drought tolerance and fast moisture release. P9494 has large, deep set grains. It has specifically large grain with high specific weight. There are often 18 grain rows on the big, thick cylindrical ears. This hybrid has very good adaptability to production sites and weather conditions.

It ranked first in its maturity group in the state examinations by the Central Agricultural Office ( $\mathrm{MgSzH})$ in 2008. Its yield exceeded the average of standard hybrids by more than 1 tonne. Its high yield stood out from its competitors in the product development trials too. In the dry and warm year of 2009 (in the second year of the registration procedure in Hungary) it ranked first again in its group and its yield exceeded the average of the standard hybrids by $800 \mathrm{~kg}$ in the official registration trials $(\mathrm{MgSzH})$. Naturally, it gave the highest yield in the FAO 300 group also in Pioneer's own trials.

In the first year of its purchase (2010) it was among the hybrids grown in the ten largest growing areas in Hungary. In 2010, as a stateregistered hybrid, $\mathrm{P} 9494$ got into the postregistration trials where it ranked first in the wet year too, exceeded again those of the competitors by significant difference in the FAO 300 group. It ranked second in 2011. Beside high yield it can be characterized by very fast drying down. Its water loss is typical of the middle of the maturity group contrary to its FAO number [3].

\section{THE WEATHER OF 2012}

After a record dry year, 2012 also proved to very dry for our country. Similarly to the situation in 2011, a large part of the year 2012 we could also characterize by the drought. Two 
months, March and August were also record dry, coupled with severe frosts in February and with long-term heat waves in summer (we went through four heat wave periods). The extreme weather (drought, heat) took a heavy toll on agriculture. Knowing the national average yield (Figure 1) it does not seem correct, that the year 2011 is listed in the drought years, because the rainfall from the previous year was stored in the soil, and the maize was able to utilize that [6].

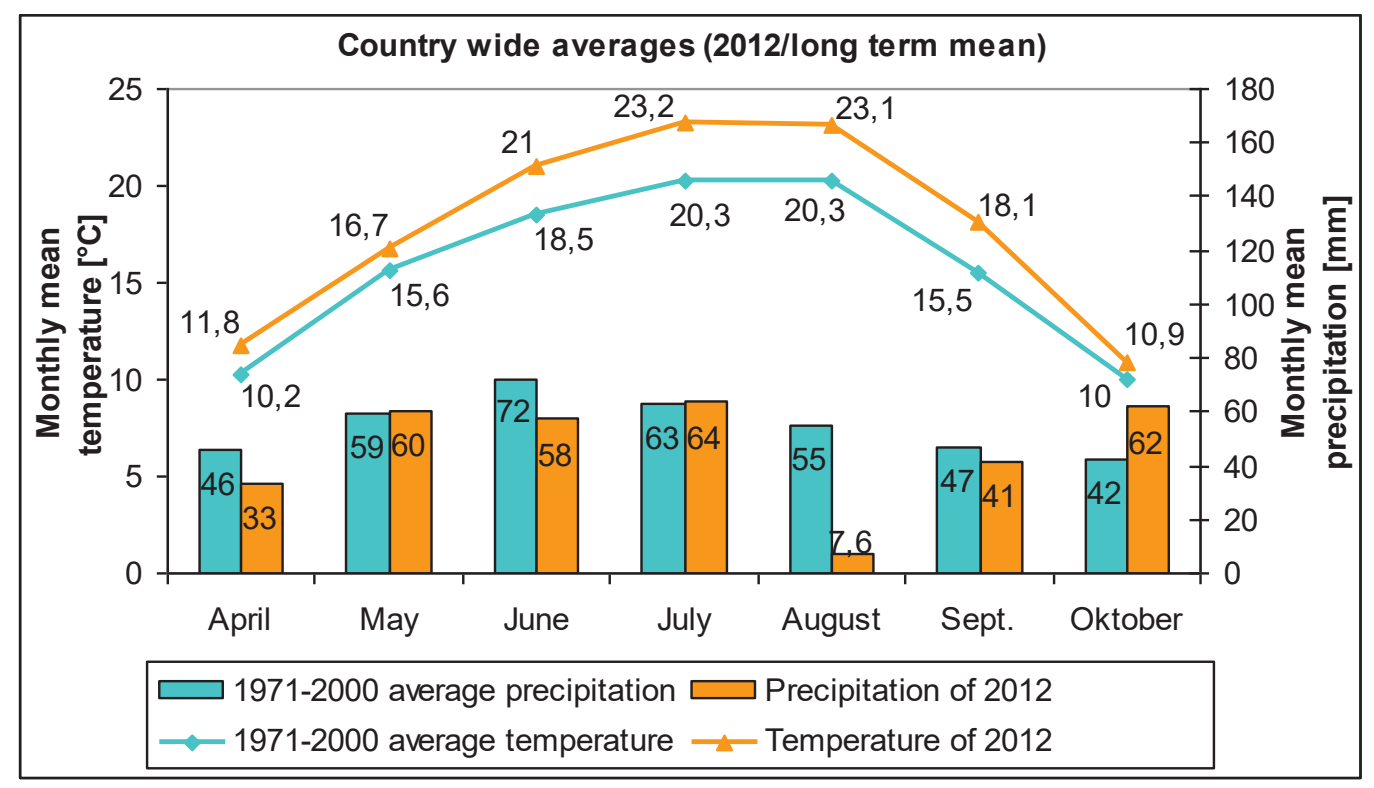

Fig. 3. Meteorological factors in maize breeding time

\section{Temperature}

In 2012, the mean temperature was higher than the long term mean temperature - except only in February (this month proved extremely cold) and in December. June and August proved to be the fourth warmest June and August since 1901 while July was the warmest July ever measured. Overall, the summer of 2012 was the second warmest summer of the past 112 years (only preceded by the summer of 2003), and this year was the fourth warmest year.

The number of heat days (when the maximum temperature exceeds $30^{\circ} \mathrm{C}$ ) recorded more than double than the national average (49 instead of 20). However, we can see the biggest difference in the number of hot days (above 35 degrees): 12 hot days were recorded instead of the usual one. During the summer we have experienced numerous long spells of hot weather as well. There were four heat waves with $27^{\circ} \mathrm{C}$ daily mean temperature or higher, within 24 heat wave days, which is the highest number recorded within a year [1].

\section{PRECIPITATION}

According to the data of the year before last that was a very dry year. We can characterize the first nine months of 2012 as severe drought - also several negative records were beaten, and only in two months, in May and in July, was the precipitation similar to the precipitation percentage of the normal 1971-2000 period. Two extraordinary extremes can be highlighted: the precipitation of March and August were far below the average value, extremely little rain fell across the country during these two months. In March only $6 \%(2 \mathrm{~mm})$ of the average precipitation fell; with this March became the driest March of the past 112 years. A similar thing happened in the eighth month as well: with $14 \%(7.6 \mathrm{~mm})$ of the average precipitation levels, the August of 2012 became the driest August since measurements started. 
Based on the amount of precipitation and the data on heat and hot days, it can be established that our weather was extremely droughty in 2012 [7].

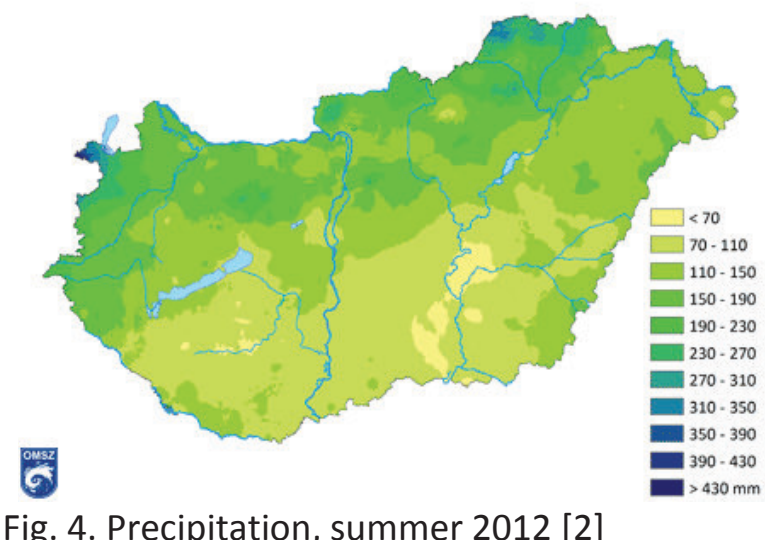

\section{RESULTS}

The investigations were executed on a 600 hectare farm in the south of the Békés County.

The first table shows the acreage, the yield and the moisture content at the time of harvesting of some hybrids. Figure 5 shows the average yields, which is calculated based on the first table's values in function of grain moisture [10].

\begin{tabular}{|c|c|c|c|c|}
\hline Producer/hybrid/FAO number & \multicolumn{2}{|c|}{ Acreage [ha] } & Product yield [t] & Water [\%] \\
\hline \multirow[t]{2}{*}{ Pioneer / P9494 / 390} & Table 1 & 36,6 & 290,97 & 11,8 \\
\hline & Table 2 & 24,4 & 198,616 & 11,9 \\
\hline \multirow[t]{2}{*}{ Monsanto / DKC 4590 / 360} & Table 1 & 52,3 & 213,384 & 12,0 \\
\hline & Table 2 & 25,2 & 92,484 & 10,9 \\
\hline Syngenta / NK Lucius / 330 & Table 1 & 33,6 & 100,128 & 10,4 \\
\hline
\end{tabular}

Table 1. The acreage, product yield and moisture per table of the varieties examined

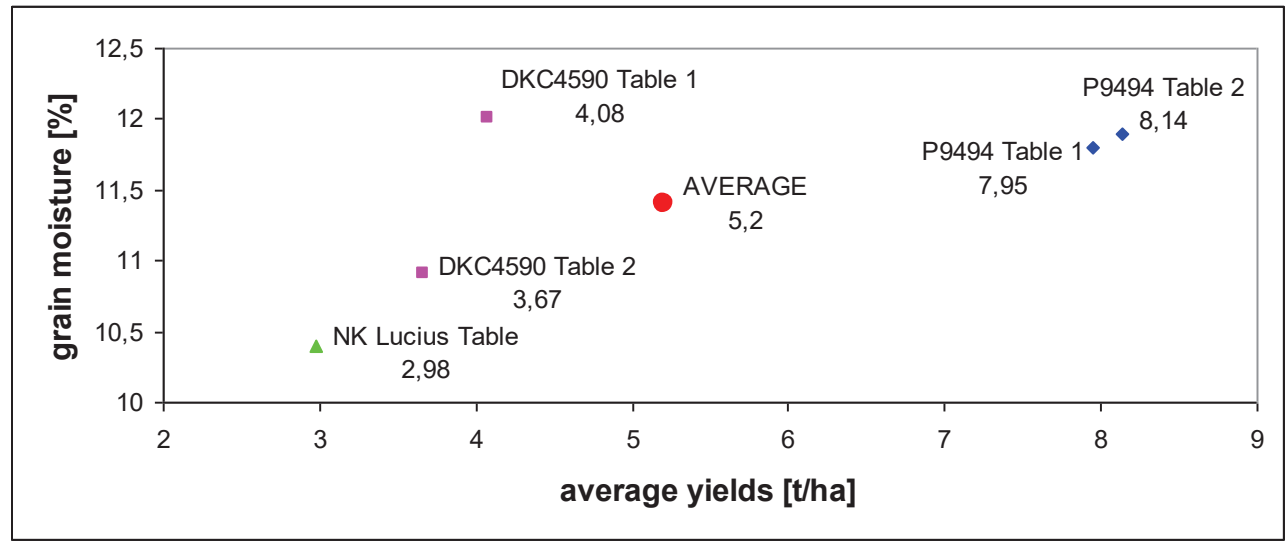

Fig. 5. The average yields per table of some species in function of grain moisture

The indicated values show that, the production site stability of the P9494 hybrid is outstanding, because there is almost imperceptible difference between the two tables. In contrast to this, in case of DKC 4590, there is more than $10 \%$ difference between the average yields of the two areas. Moreover, it can be established that the Monsanto hybrid showed very hectic changes within one table in terms of its yields.

The P9494 hybrid - according to references in literature - performs above the average espe- cially in stressful years, like the one experienced two years ago. Its excellent stress tolerance was pulled through in critical periods (dry periods), and beat all its rivals with yields in excess of 8 tons ( $8.03 \mathrm{t} / \mathrm{ha}$ ) found in this investigation.

DKC 4590's average yield (3.95 t/ha) was just less than half of the Pioneer's performance and it corresponded to the average yield found in Hungary. On the whole it can be stated that the performance of this type was a big disappointment to the author. 
Lucius, contrary to the expectations, did not confirm anything from the previous experiments where it showed a great performance. It reached only an extremely weak average yield (2.98 t/ha) from 33.6 hectare cropland. The lowest yield per hectare was performed by Syngenta's top hybrid type yielding not more than $37 \%$ of the P9494 hybrid and only threequarters of DKC 4590. However, the grain moisture of Lucius - although not significantly - was lower (its water loss is really faster) than the other species, even though in year 2012 it turned out a disadvantage, because of the low water high shatter loss arising at harvesting.

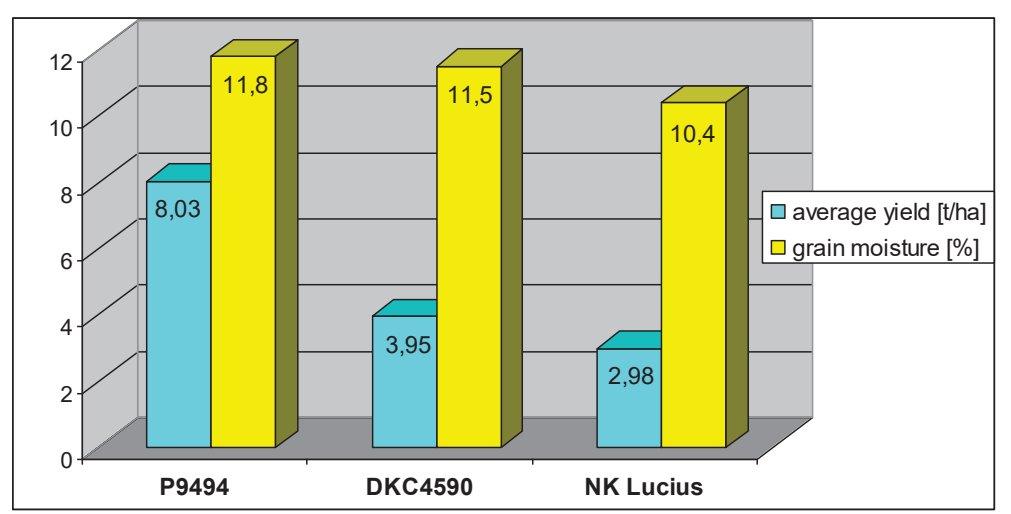

$9.5 \mathrm{q} / \mathrm{ha}$, while Dekalb reached $11.5 \mathrm{q} / \mathrm{ha}$ results) cannot be compared with the values of the year 2012 (Figure 6), but these differences should not be merged into one same maturity group and with the same conditions. It would be interesting to compare these varieties in completely different weather conditions, so the investigation certainly will continue this year.

\section{CONCLUSIONS}

The experiences of the year 2012: for a lot of things we cannot find a logical explanation. We can describe that the fields were not irrigated, so the only water source was the natural rainfall; till the end of September in that area reached only $300 \mathrm{~mm}$. We have to add, however, that there was a critical lack of rain two years earlier; on an average the deficiency of moisture was $200-250 \mathrm{~mm}$. Therefore the nutrient utilization was not optimal, and in this respect the fertilization effect was infinitesimal.
Fig. 6. The aggregated average yield and grain moisture of some species

It should be also noted that the flowering of the stands and the grain setting were in progress when the hot days arrived. The heat stress, which all three hybrids were exposed to, caused a significant yield depression. All of this is well reflected in $5.2 \mathrm{t} / \mathrm{ha}$ average yield, too. On further investigation with the values obtained, perhaps it could be established that in such extreme drought years, varieties with higher FAO numbers flatter higher yields, but for instance in this very same farm DKC 5007 (FAO 450) Monsanto hybrid (belonging to the medium-early maturity group) reached just $7.26 \mathrm{t} /$ ha performance, wherewith it outranked DKC 4590 (FAO 360), but could not exceed the performance of P9494.

Naturally, the average yield of previous years (in year 2011, at the same farm Lucius yielded
Maybe it can be established that the hybrids' drought-tolerant feature differs from the figures given in their catalogue. Obviously, it is not indicated which of these hybrids were tested for that extremely dry and hot weather, too. While the spring emergence was trouble-free (sowing time was between 14-18 April, all hybrids were sown with a density of 73,750 plants per hectare, sowing distance was $75 \mathrm{~cm}$ ), the plants came up at the same time, but there was one control plot, which was not treated with micro-granular starter fertilizer. To tell the truth, between the emergence and the development of the maize, visible, measurable differences did not arise.

It should be noted, however, that the region was hit by an exceptional moth infection and the protection applied resulted only in partial success in that year. Furthermore, during the harvest (hybrids could be harvested between 15-22 September) the unusual dry maize grains 
required very careful attention, because these grains could easily crackle, which can cause and did cause significant or measurable losses. Naturally, because of the moth damage cautious harvest was called for and therefore the ears did not fall out prematurely from the adapter.

With this information available, growers will be smart enough to choose the technology and type of hybrid to buy for the next years. In the neighbouring area there were farmers who did not buy top hybrids, did not apply intensive technology and their yields were not worse than the averages described here. Thus the question arises, which hybrid type and technology will be chosen for long-term use?

\section{SUMMARY}

We should not forget that our country has changeable and sometimes extreme weather conditions. In year 2012, the exposure of our agriculture to extreme conditions became visible, which can be mitigated with only one option, namely water management including the expansion of irrigation capacity. In those years when there were excess high temperatures but serious lack of precipitation did not occur, lower yield-depression was caused by the heat.

Furthermore, at selection of the maize hybrids mentioned above - the economical cultivation is basically tampered - productivity and drying down capacity in addition to the yield safety, predictability, stability and also some species' stress tolerance became more important, which became a main attribute again two years ago.

\section{REFERENCES}

[1.] http://www.met.hu/eghajlat/magyarorszag_eghajlata/eghajlati_visszatekinto/elmult_eve k_idojarasa/

[2.] http://www.met.hu/eghajlat/magyarorszag_eghajlata/eghajlati_visszatekinto/elmult_evs zakok_idojarasa/

[3.] http://hungary.pioneer.com/Termékajánlat/Kukorica/FA0300399/P9494FAO390.aspx

[4.] http://www3.syngenta.com/country/hu/hu/szantofoldi_vetomagok/novenyeink/kukorica /NKLucius.aspx

[5.] Kukorica vetőmag ajánlat 2012 - Dekalb katalógus

[6.] Pákozdi I.: Kihagyhatatlan Pioneer hibridek, AgroNapló 16. évf. 1. sz. 2012. január, Kiadó: Zsigmond Kft. p. 22-24.

[7.] Széll E., Szél S., Makra M.: A 2012. évi kukoricatermesztési kísérletek eredményei az előző évek adatainak összehasonlításában, Agrofórum Extra 47. 2012. december, p. 40-45.

[8.] FAOSTAT database: Maize in Hungary, http://faostat.fao.org

[9.] László R.: Egy vetőmagelőállító üzem feldolgozási folyamatának logisztikaorientált felülvizsgálata, Szakdolgozat, Szolnoki Főiskola, Szolnok, 2011. p. 71. [konzulens: Oláh B.]

[10.] Oláh B.: Korai érésű kukorica hibridek 2012. évi összehasonlítása a termésátlag függvényében, Műszaki Tudomány az Észak-kelet Magyarországi Régióban 2013, Debrecen, 2013. p. 308-316.

[11.] KWS vetőmag ajánlat 2014.

http://www.kws.de/global/show_document.asp?id=aaaaaaaaaaomfiu 